\title{
INDUKSI EMBRIO SOMATIK Shorea pinanga Scheff. PADA KONDISI FISIK MEDIA BERBEDA
}

Somatic Embryos Induction of Shorea pinanga Scheff. in Different Physical Condition Media

\author{
Yelnititis \\ Balai Besar Penelitian Bioteknologi dan Pemuliaan Tanaman Hutan \\ Jl. Palagan Tentara Pelajar Km. 15, Purwobinangun, Pakem, Sleman, Yogyakarta 55582 \\ e-mail :yelnititis@yahoo.com
}

\begin{abstract}
Shorea pinanga (Scheff.) is a member of Dipterocarpaceae which has an important role both as a forest timber and also non forest timber product (tengkawang). The purpose of this experiment is to obtain the best treatment for somatic embryos formation. Friable callus was used as explants whereas liquid and solid MS media supplemented with vitamin $B, 30 \mathrm{~g} / \mathrm{l}$ sucrose were used as basal medium. Embryogenic callus was induced through three times subcultured in basal medium with $5.0 \mathrm{mg} / \mathrm{l} \mathrm{2,4-}$ D. Somatic embryo was induced using $100 \mathrm{mg}$ of embryogenic callus with the addition of 0.5, 1.0, and $1.5 \mathrm{mg} / \mathrm{l}$ kinetin. The observation was done on texture, numbers and color of embryogenic callus and weekly number of somatic embryos for eight weeks. The kinetin treatment of $1.5 \mathrm{mg} / \mathrm{l}$ on liquid medium was the best treatment because it is able to induce 162 cotyledonary stage of somatic embryos for eight weeks.
\end{abstract}

Keywords: Friable callus, embryogenic callus, somatic embryo, Shorea pinanga.

\begin{abstract}
ABSTRAK
Meranti (Shorea pinanga Scheff.) merupakan salah satu anggota suku Dipterocarpaceae yang mempunyai peranan penting sebagai penghasil kayu dan penghasil tengkawang. Penelitian induksi embrio somatik pada kondisi fisik media berbeda, bertujuan untuk mendapatkan metoda terbaik dalam pembentukan embrio somatik. Kalus remah dijadikan sebagai eksplan. Media dasar MS dalam bentuk cair dan padat yang diperkaya dengan $30 \mathrm{~g} / 1$ sukrosa dan vitamin B dijadikan sebagai media tumbuh. Induksi kalus embriogenik dilakukan melalui pemindahan kalus sebanyak 3 kali pada media padat dengan penambahan 5,0 mg/1 2,4-D. Induksi embrio somatik dilakukan dengan menggunakan $100 \mathrm{mg}$ kalus embriogenik pada media padat dan media cair yang ditambah dengan 0,$5 ; 1,0 ;$ dan $1,5 \mathrm{mg} / 1$ kinetin. Perlakuan $1,5 \mathrm{mg} / \mathrm{l}$ kinetin pada media cair merupakan perlakuan terbaik untuk menginduksi embrio somatik dengan rata-rata jumlah embrio somatik fase kotiledon sebanyak 162 dalam 8 minggu.
\end{abstract}

Kata kunci : Kalus remah, kalus embriogenik, embrio somatik, Shorea pinanga.

\section{PENDAHULUAN}

Embriogenesis somatik merupakan pembentukan, pertumbuhan dan perkembangan embrio dari sel-sel soma atau dari sel-sel tubuh tanaman (Ammirato, 1983). Embriogenesis somatik merupakan salah satu teknik perbanyakan in vitro yang paling menguntungkan untuk spesies yang mempunyai nilai ekonomi tinggi (Blanc et al., 1999) karena mempunyai beberapa keuntungan antara lain jumlah tanaman yang diperoleh jauh lebih banyak, populasi tanaman yang dihasilkan identik dengan tetuanya, dan embrio somatik tersebut dapat 
berkembang menjadi plantlet (Rani dan Raina, 2000). Teknik ini dapat diotomatisasi dengan menggunakan bioreaktor untuk menghasilkan embrio somatik dalam jumlah sangat banyak (Yoeup dan Chakrabarty, 2003).

Molina et al. (2002) mengatakan bahwa embrio somatik dapat terjadi secara langsung dan secara tidak langsung. Embriogenesis somatik langsung merupakan pembentukan embrioid yang langsung berasal dari jaringan tanpa adanya proliferasi kalus, sedangkan embriogenesis somatik tidak langsung diawali dengan pembentukan kalus dan embrioid dapat dihasilkan melalui budidaya kalus maupun suspensi sel (Noerhadi, 1988). Kalus remah umumnya dicirikan oleh selselnya yang mudah dipisahkan dan dapat berkembang membentuk kalus embriogenik. Kalus embriogenik dapat diinduksi dengan menggunakan zat pengatur tumbuh dari kelompok auksin antara lain 2,4-D (2,4-Dichlorophenoxyacetic acid) (Litz, et al. 1998), NAA (Naphthalene Acetic Acid) (Nugent et al. 2001) dan dicamba (Sagare et al. 1993). Selanjutnya embrio somatik diinduksi dengan penurunan konsentrasi auksin dan atau tanpa penambahan zat pengatur tumbuh dari kelompok sitokinin.

Perbanyakan tanaman Shorea sp. melalui budidaya suspensi telah dilakukan oleh Gunasekara et al. (1988) tetapi belum diperoleh embrio somatik. Selanjutnya Umboh et al. (1992) mendapatkan kalus embrional dari eksplan potongan embrio. Demikian juga Yelnititis et al. (2002) mendapatkan kalus kompak dari eksplan meristem $S$. leprosula dan $S$. selanica pada media MS (Murashige dan Skoog, 1962) dan media B5 (Gamborg, 1968) yang ditambah dengan 0,1 - 1,0 mg/1 2,4-D dikombinasikan dengan 0.5 dan 1,0 mg/l NAA. (Yelnititis (2007) mendapatkan embrio somatik dari eksplan potongan embrio $S$. pinanga dari perlakuan $4,0 \mathrm{mg} / \mathrm{l}$ dan $5,0 \mathrm{mg} / 1$ 2,4D tetapi jumlah yang diperoleh masih rendah.) Embrio somatik dihasilkan dengan menumbuhkan kalus embriogenik pada $20 \mathrm{ml}$ media perlakuan, ditempatkan dalam ruangan dengan suhu $18^{\circ} \mathrm{C}-30^{\circ} \mathrm{C}$, intensitas cahaya 10.000 lux dengan penerangan cahaya selama 16 jam/hari dan kelembaban sekitar $40 \%-80 \%$. Menurut Young et al. (2000) pembentukan embrio somatik pada tanaman kakao dilakukan pada ruangan dengan intensitas cahaya 50 $\mu \mathrm{mol} \cdot \mathrm{m}^{-2} \cdot \mathrm{s}^{-1}$ dan suhu $20^{\circ} \mathrm{C}-30^{\circ} \mathrm{C}$. Dari hal di atas perlu dicari metode yang sesuai untuk mendapatkan embrio somatik dalam jumlah yang optimal.

\section{METODE PENELITIAN}

Penelitian dilakukan di Laboratorium Kultur Jaringan, Balai Besar Penelitian Bioteknologi dan Pemuliaan Tanaman Hutan, Yogyakarta dari bulan Juni 2006 sampai bulan Mei 2007.

Kalus yang digunakan sebagai eksplan 
adalah kalus remah dari potongan embrio muda $S$. pinanga Scheff. Medium dasar MS digunakan sebagai media tumbuh untuk menghasilkan kalus embriogenik. Kalus friabel ditumbuhkan pada perlakuan $5,0 \mathrm{mg} / 1$ 2,4-D selama 5 minggu kemudian dilakukan pemindahan sebanyak 3 kali dengan selang waktu yang sama yaitu selama 5 minggu. Untuk induksi embrio somatik, sebanyak 100 mg kalus embriogenik ditumbuhkan pada media padat dan media cair dengan perlakuan penambahan 0,$5 ; 1,0$ dan 1,5 $\mathrm{mg} / \mathrm{l}$ kinetin dan dibiarkan selama 8 minggu. Pengamatan dilakukan terhadap jumlah embrio somatik fase kotiledon dan penampilan visual embrio somatik yang dihasilkan. Data morfologi dan histologi yang diperoleh dianalisis secara deskriptif.

\section{HASIL DAN PEMBAHASAN}

\section{A. Pertumbuhan kalus menjadi kalus embriogenik.}

Kalus yang digunakan sebagai eksplan dalam penelitian ini adalah kalus yang sangat remah yang sel-selnya mudah terpisah dan berwarna putih kekuningan (Gambar 1a). Kalus tersebut mempunyai kandungan air yang lebih banyak dibandingkan dengan kalus kompak. Kalus remah yang ditumbuhkan pada media MS padat dengan penambahan 5,0 mg/l 2,4-D mudah memperbanyak diri, mengalami pertumbuhan yang sangat cepat dan secara perlahan memperlihatkan perkembangan. Perubahan tersebut dapat dilihat pada bentuk, ukuran dan teksturnya. Adanya pertumbuhan kalus menyebabkan ukuran kalus menjadi lebih besar. Selain itu kalus tersebut menjadi lebih padat dengan tekstur yang tetap friabel dan berwarna putih kekuningan (Gambar 1b).

Setelah diinkubasi selama 15 minggu kalus friabel berkembang menjadi kalus embriogenik (Gambar 1c). Umumnya pembentukan kalus embriogenik pada tiap spesies tanaman berbeda-beda. Dalam penelitian ini kalus embriogenik dapat terbentuk melalui pemindahan berulang sebanyak 3 kali dengan selang waktu selama 5 minggu pada perlakuan yang sama. Hasil penelitian Shrikhande et al. dalam Su et al. (1997) secara berbeda menunjukkan bahwa kalus embriogenik dihasilkan dalam jangka waktu yang lebih cepat yaitu setelah dua kali pemindahan pada media yang sama.

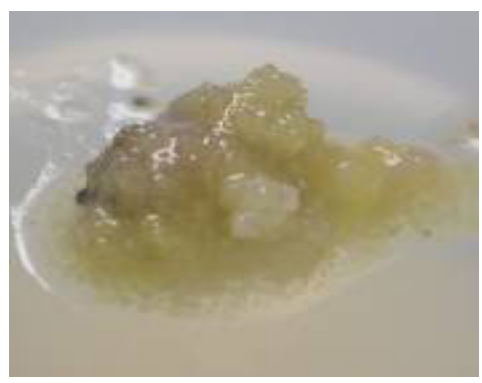

a

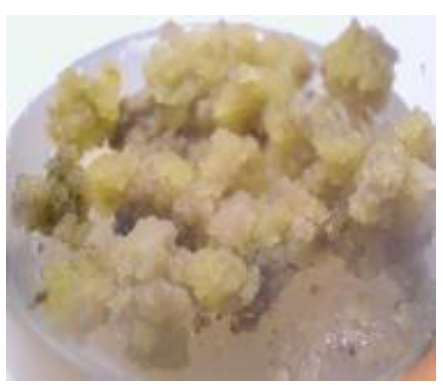

b

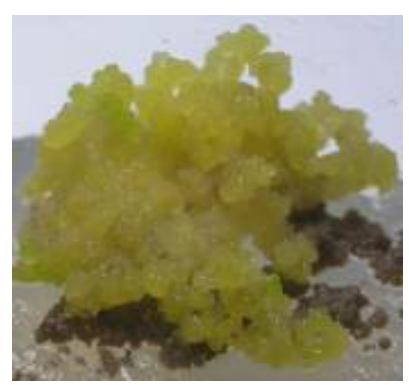

$\mathrm{c}$

Gambar 1. Kalus friabel pada umur a. 6 minggu, b. 12 minggu dan c. Kalus embriogenik. 
Kalus friabel yang diperoleh dari penelitian ini merupakan kalus yang dapat mengikuti pola embriogenesis somatik. Sel-sel kalus yang mengikuti pola embriogenesis somatik dapat berkembang membentuk kalus embriogenik dan selanjutnya menjadi embrio somatik mulai dari fase globular sampai fase kotiledon. Penggunaan perlakuan yang berbeda memberikan pengaruh yang berbeda terhadap kalus yang ditumbuhkan karena adanya kompetisi antara sel embriogenik dalam pertumbuhan maupun perkembangannya. Perbedaan dari masing-masing perlakuan tersebut dapat dilihat pada tekstur maupun warna kalus yang diperoleh. Jaringan yang menyentuh media lebih mudah menyerap hara dan zat pengatur tumbuh sehingga pertumbuhannya juga berbeda dibandingkan dengan kalus yang berada di bagian permukaan. Adanya persaingan dalam penyerapan hara dari media yang digunakan menentukan arah dan kemampuan tumbuh yang berbeda, sehingga dihasilkan embrio somatik dengan fase dan jumlah yang juga berbeda. Hasil yang sama dihasilkan dari penelitian Shimizu et al. (1997) yaitu kalus yang berwarna kekuningan pada tanaman Iris germanica dapat berkembang membentuk embrio somatik yang selanjutnya menjadi plantlet.

Pertambahan sel-sel kalus pada perlakuan ini berlangsung dengan cepat. Hal ini ditunjukkan dengan waktu pertambahan kalus yang jauh lebih singkat dan mencapai jumlah maksimum. Pada penelitian ini penggunaan 5,0 mg/l 2,4-D secara terus-menerus merangsang kalus friabel berkembang menjadi kalus embriogenik. Inisiasi kalus embriogenik terjadi sebagai pengaruh dari cekaman akibat pengaruh konsentrasi auksin yang relatif tinggi karena penggunaan zat pengatur tumbuh dalam jangka waktu yang lama dapat meningkatkan kandungan hormon endogen kalus yang ditumbuhkan. Selanjutnya Yelnititis (2007) dan Yelnititis (2008) menyatakan bahwa perlakuan $5,0 \mathrm{mg} / 1$ 2,4-D merupakan perlakuan terbaik untuk menginduksi kalus embriogenik pada jenis tanaman yang sama. Sel-sel dari kalus yang sama mempunyai kemampuan yang berbeda dalam membentuk kalus embriogenik yang selanjutnya dapat berkembang menjadi embrio somatik. Selain itu kalus embriogenik yang dihasilkan mempunyai penampilan visual yang baik, berwarna kekuningan, nodular, remah (Gambar 2 a dan e) dan dapat berkembang membentuk embrio somatik mulai dari fase globular sampai fase kotiledon pada media cair (Gambar 2b - 2d) maupun pada media padat (Gambar 2f - 2h). Hasil yang sama dihasilkan dari penelitian Ortiz et al. (2000) yang menunjukkan bahwa kalus embriogenik yang berasal dari embrio zigotik muda dapat berkembang membentuk embrio somatik. 


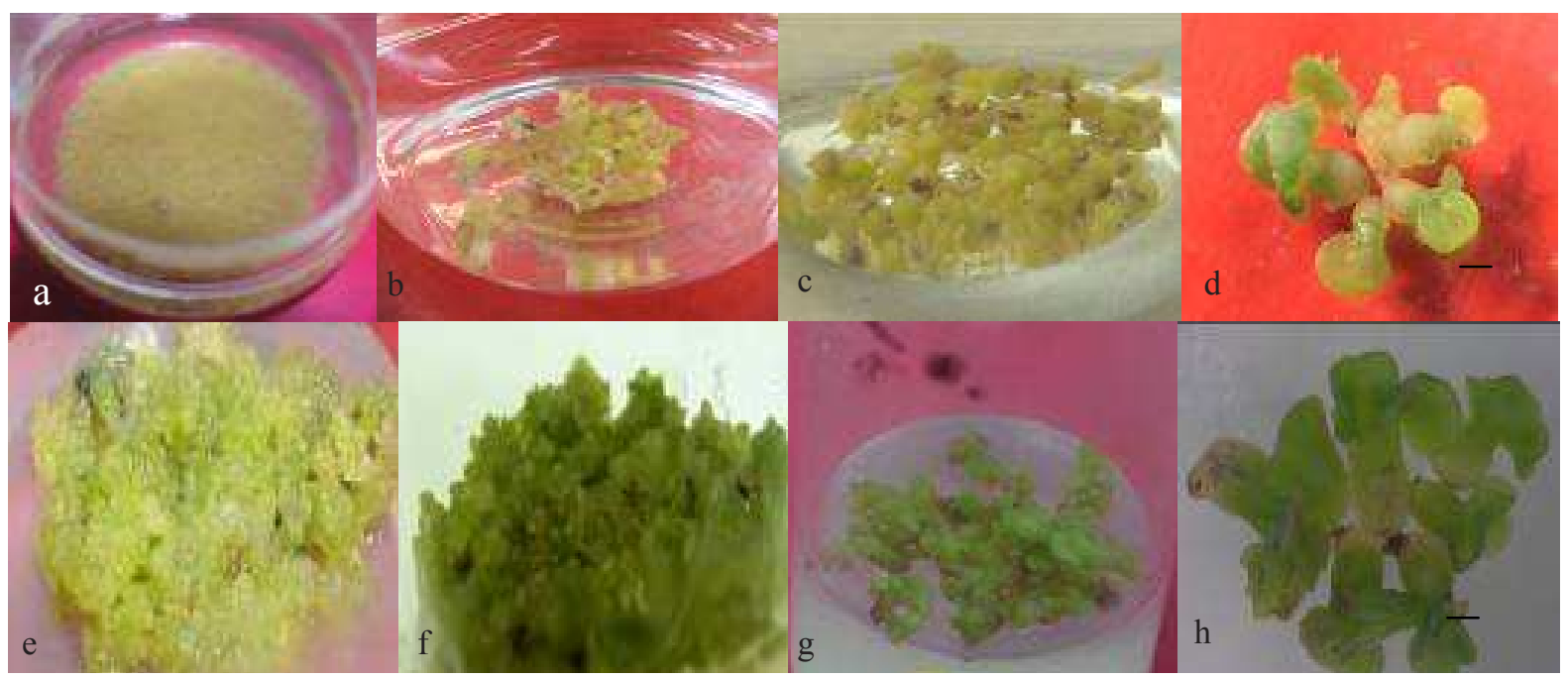

Gambar 2.Perkembangan kalus embriogenik menjadi embrio somatik, atas. Pada media cair, a. eksplan kalus embriogenik, b - c. Embrio somatik pada umur 2 dan 5 minggu dan d. Embrio somatik fase kotiledon; bawah. Pada media padat : e. Eksplan kalus embriogenik, f - g. Embrio somatik umur 2 dan 5 minggu dan h. Embrio somatik fase kotiledon.

\section{B. Induksi embrio somatik.}

Penggunaan media padat dan media cair dapat merangsang kalus embriogenik berkembang membentuk embrio somatik. Kedua jenis media tersebut memberikan pengaruh terhadap embrio somatik yang dihasilkan. Hal tersebut dapat dilihat pada ukuran, warna dan waktu terbentuknya embrio somatik.

Penggunaan media cair memberikan pengaruh yang lebih cepat terhadap pembentukan embrio somatik. Hal ini disebabkan karena penyerapan hara pada media cair lebih cepat dibandingkan pada media padat sehingga pertumbuhan dan perkembangan kalus embriogenik menjadi embrio somatik juga lebih cepat. Ratarata waktu terbentuknya embrio somatik pada media cair antara 49,3 sampai 50,0 hari setelah ditumbuhkan, sedangkan pada media padat antara 69,4 hari sampai 71,2 hari. Peningkatan penggunaan kinetin pada media cair tidak memberikan pengaruh yang nyata terhadap waktu terbentuknya embrio somatik, demikian juga dengan penggunaan media padat. Penggunaan media cair $+1,5$ $\mathrm{mg} / \mathrm{l}$ kinetin merupakan perlakuan yang paling cepat untuk induksi embrio somatik. Rata-rata induksi embrio somatik dari perlakuan ini terjadi setelah 49,3 hari dan tidak berbeda nyata dengan perlakuan yang lain. Hasil penelitian Concha et al. (2012) menyatakan bahwa induksi embrio somatik dari eksplan potongan embrio zigotik pada tanaman Gomortega keule terjadi setelah 7 bulan, jenis dan konsentrasi zat pengatur tumbuh yang digunakan tidak berpengaruh terhadap pembentukan embrio somatik. Selain waktu yang lebih cepat, embrio somatik yang dihasilkan dari media cair juga berukuran lebih kecil dibandingkan dengan penggunaan media padat. Embrio somatik yang dihasilkan pada media cair berukuran antara 0,4-0,7 cm (Tabel 2) serta berwarna 
hijau muda. Pembentukan embrio somatik pada media padat terjadi antara $69,4-71,2$ hari. Embrio mempunyai ukuran yang lebih besar dan panjang antara 0,7-0,9 cm (Tabel 1) dan berwarna hijau tua (Gambar $2 \mathrm{e}-2 \mathrm{~h}$ ). Adanya perbedaan tersebut merupakan hasil interaksi yang sangat komplek antara kalus, komposisi media tumbuh, zat pengatur tumbuh dan kondisi lingkungan selama periode inkubasi (Indrianto, 2002).

Perkembangan kalus embriogenik menjadi embrio somatik merupakan aktivitas dari beberapa faktor. Dalam perkembangannya kalus embriogenik melalui beberapa fase yaitu fase globuler, jantung, torpedo dan kotiledon. Kalus embriogenik yang umumnya mempunyai bentuk isodiametrik berwarna putih kekuningan, secara perlahan berubah bentuk menjadi globular dengan permukaan sel yang lebih halus. Selain itu ukuran sel menjadi lebih besar dan berwarna hijau. Perubahan yang terjadi pada kalus embriogenik dapat dilihat setelah 7 hari dibudidayakan. Semuakalus tersebutberubah warna menjadi hijau setelah dibudidayakan selama 14 hari. Permukaan kalus terlihat halus dan mengkilat. Waktu tersebut merupakan saat mulai terbentuknya embrio somatik fase globular yang berkembang sampai fase kotiledon. Hasil penelitian ini sama dengan penelitian Capuana dan Deberg (1997) yang menunjukkan bahwa pertumbuhan embrio somatik merupakan aktifitas dari sitokinin pada saat diferensisasi sel-sel kalus. Selanjutnya hasil penelitian Veisseire et al. (1994) yang menyatakan bahwa untuk merangsang terbentuknya embrio somatik pada tanaman Picea abies digunakan kombinasi antara kinetin, $9 \mu \mathrm{M}$ BA (6-Benzyl adenine) dan 2,4-D.

Tabel 1. Penampilan visual embrio somatik fase kotiledon pada media padat dan media cair.

\begin{tabular}{|c|c|c|c|}
\hline Jenis media & Bentuk & Panjang $(\mathrm{cm})$ & Warna \\
\hline Padat & normal & $0,7-0,9$ & Hijau \\
\hline Cair & normal & $0,4-0,7$ & Hijau muda \\
\hline
\end{tabular}

Tabel 1 memperlihatkan kedua jenis media sama-sama menghasilkan embrio somatik normal yang dicirikan dengan adanya kotiledon dan calon akar. Dari semua perlakuan kinetin yang diuji dapat dihasilkan embrio somatik fase kotiledon (Gambar 2d dan 2h) setelah dibudidayakan selama 8 minggu. Hasil penelitian ini berbeda dari penelitian Dai et al. (2011) yang menunjukkan bahwa embrio somatik dihasilkan dalam waktu lebih cepat yaitu 5 minggu. Proembrio berkembang menjadi embrio somatik fase globular, fase hati, fase kotiledon dan selanjutnya menjadi embrio somatik fase kotiledon. Hasil penelitian Lee et al. (2002) menunjukkan bahwa embrio fase globular dibentuk pada medium cair tanpa penambahan zat pengatur tumbuh yang selalu dipindahkan pada media yang sama, sedangkan dari pemindahan kalus ke 
dalam media dengan penambahan $0,76-7,6$ $\mu \mathrm{M}$ ABA (Abscisic acid) dihasilkan embrio somatik fase globular dengan jumlah yang lebih banyak, tetapi embrio somatik fase torpedo serta fase kotiledon dengan jumlah yang lebih rendah dari perlakuan kontrol. Menurut Singh et al. (1999) perkembangan embrio somatik dipengaruhi oleh jenis media dan konsentrasi kinetin yang digunakan. Selanjutnya Guevin et al. (1994) dalam Guevin dan Kirby (1997) menyatakan bahwa penggunaan sitokinin secara tunggal efektif untuk induksi embrio somatik dari eksplan embrio zigotik Abies fraseri. Hasil penelitian yang berbeda dilaporkan oleh Nanda dan Rout (2003) yang menyatakan bahwa untuk pembentukan embrio somatik digunakan BA yang dikombinasikan dengan 2,4-D. Penelitian Rai dan McComb (2002) menunjukkan bahwa perlakuan media dengan penambahan $4.5 \mu \mathrm{M}$ thidiazuron memberikan rata-rata jumlah embrio somatik paling tinggi sedangkan perlakuan dengan penambahan $6,4 \mu \mathrm{M}$ BA memberikan ratarata jumlah embrio somatik paling rendah. Embrio somatik fase kotiledon yang diperoleh dari perlakuan ini mempunyai dua kotiledon. Hal ini berarti bahwa embrio yang diperoleh dari teknik ini mempunyai bentuk normal seperti embrio zigotik biasa.

Penggunaan semua konsentrasi kinetin pada kedua jenis media yang digunakan dapat membentuk embrio somatik. Perlakuan media cair dengan kinetin 1,5 mg/1 merupakan perlakuan terbaik untuk induksi embrio somatik fase kotiledon. Rata-rata jumlah embrio somatik fase kotiledon yang dihasilkan dari perlakuan ini paling banyak yaitu sebanyak 162, sedangkan perlakuan media padat dengan kinetin $1.5 \mathrm{mg} / \mathrm{l}$ merupakan perlakuan terbaik untuk induksi embrio fase globular dengan jumlah rata-rata sebanyak 271. Selain itu juga dapat dilihat bahwa peningkatan konsentrasi kinetin pada kedua jenis media yang digunakan juga meningkatkan jumlah embrio somatik fase globular, fase torpedo, fase kotiledon pada media padat serta fase kotiledon pada media cair. Hal ini menunjukkan bahwa untuk induksi embrio somatik pada jenis ini dibutuhkan zat pengatur tumbuh kinetin dengan konsentrasi yang tidak terlalu tinggi. Berbeda dari penelitian (Rohani et al., 2012) menunjukkan bahwa embrio somatik dari eksplan potongan daun manggis tidak dihasilkan pada media yang mengandung kinetin. Selanjutnya Yang et al. (2012) menyatakan bahwa untuk induksi embrio somatik dibutuhkan zat pengatur tumbuh NAA.

Dilihat dari proses perkembangan anatomi embrio somatik yang dihasilkan, terjadi perubahan bentuk dan pertambahan ukuran terutama pada ukuran panjang. Proembrio berkembang membentuk embrio somatik fase globular setelah satu minggu dibudidayakan. 


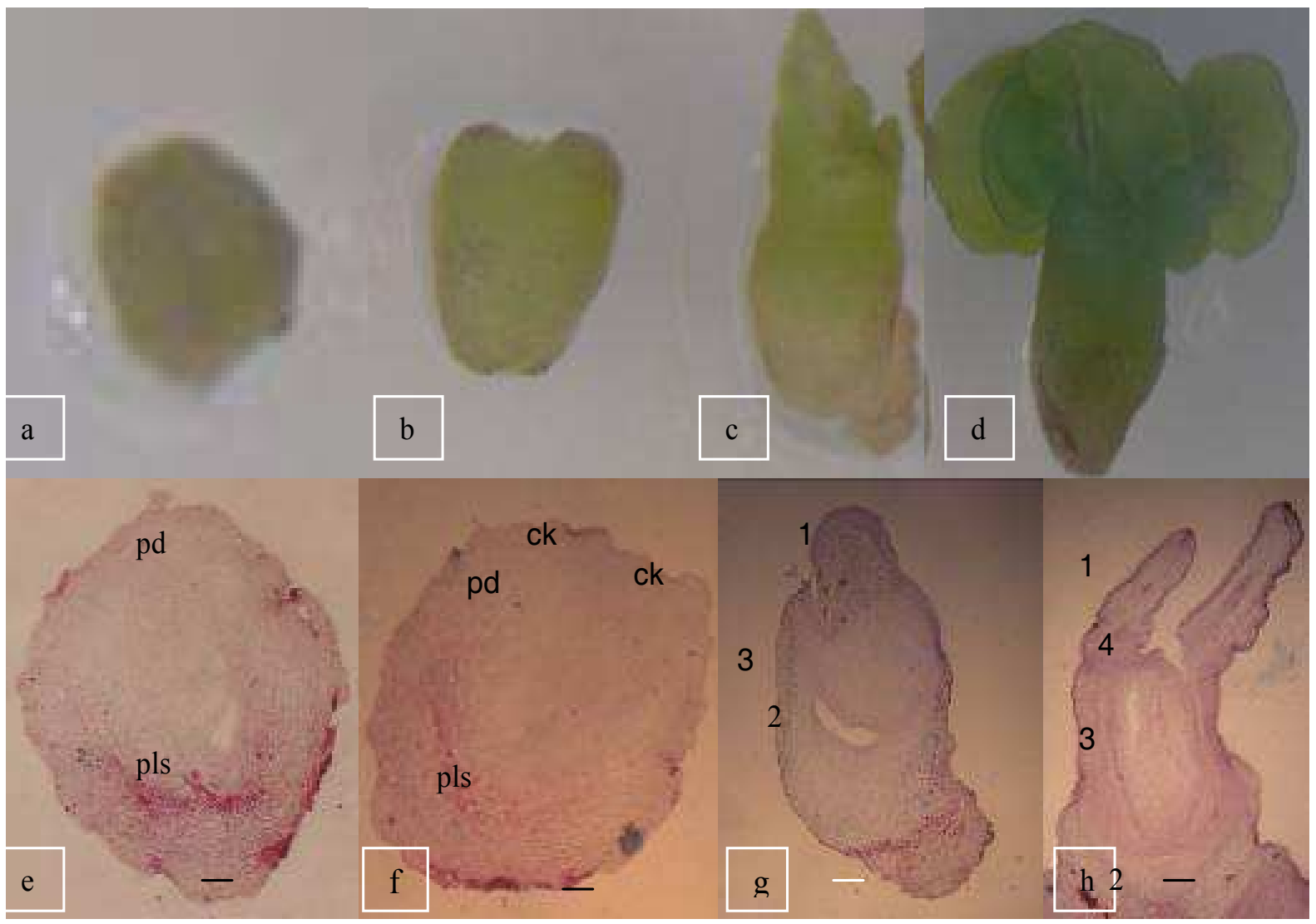

Gambar 3. Embrio somatik. a. fase globuler; b. fase jantung; c. fase torpedo; d. fase kotiledon, e. penampang membujur embrio fase globuler; pls (procambium-like structure); pd (protoderm); f. penampang membujur embrio fase jantung; pd (protoderm); ck. (calon kotiledon); pls (procambium-like structure), g. penampang membujur embrio fase torpedo; 1 (kotiledon); 2 (calon akar); 3. (berkas pembuluh); 4 (meristem apikal); h. penampang membujur embrio fase kotiledon. 1. kotiledon; 2. calon akar; 3 . berkas pembuluh; 4 . meristem apikal. skala $\mathrm{a}=0,3 \mathrm{~mm} ; \mathrm{b}=0,5 \mathrm{~mm} ; \mathrm{c}=0,8 \mathrm{~mm} ; \mathrm{d}=$ $0,4 \mathrm{~mm}$. e $=257 \mu \mathrm{m} ; \mathrm{f}=500 \mu \mathrm{m} ; \mathrm{g}=1 \mathrm{~mm} ; \mathrm{h}=1,2 \mathrm{~mm}$.

Embrio somatik fase globular (Gambar 3a dan 3e) dicirikan dengan bentuk yang bulat atau membulat. Embrio somatik fase globular berkembang menjadi fase hati. Leyser dan Day (2002) menyatakan bahwa embrio somatik fase hati diawali dengan pembentukan satu atau dua kotiledon namun secara visual fase hati tidak dapat diamati. Terbentuknya kotiledon dimulai dengan adanya lekukan yang membentuk dua area. Selanjutnya Yeung (1995) menyatakan bahwa kotiledon pada tanaman dikotil muncul dari bagian perifer sebagai tonjolan kecil pada bagian terminal embrio somatik.
Dari fase hati embrio somatik berkembang dengan membentuk dua kotiledon (ck) yang terdapat pada bagian atas tetapi masih pendek (Gambar 3b dan 3f). Dua minggu setelah inkubasi, daerah ini memperlihatkan perkembangan lanjut dan struktur bipolar semakin jelas. Pada tahap ini embrio somatik berada pada fase torpedo. Hal ini ditandai dengan pemanjangan embrio dan pemanjangan kotiledon. Menurut Leyser dan Day (2003) embrio fase jantung memanjang membentuk embrio fase torpedo dengan pola jaringan yang sama. Setelah dibudidayakan selama 5 minggu embrio fase torpedo 
mengalami perkembangan membentuk embrio somatik fase kotiledon (Gambar 3c dan $3 g$ ). Pada fase ini kotiledon mengalami pertumbuhan memanjang sehingga embrio somatik pada tahap ini berada pada fase kotiledon (Gambar 3d dan 3h). Pada fase ini dapat dilihat polaritas embrio somatik yang sangat jelas. Pembentukan kotiledon merupakan proses morfogenetik yang penting dalam embriogenesis somatik.

\section{KESIMPULAN}

Embrio somatik dapat dihasilkan pada media padat dan media cair yang digunakan. Media cair MS yang ditambah $1,5 \mathrm{mg} / \mathrm{l}$ kinetin merupakan perlakuan terbaik untuk pembentukan embrio somatik fase kotiledon dengan jumlah rata-rata sebanyak 162, sedangkan media MS padat yang ditambah $1,5 \mathrm{mg} / 1$ kinetin merupakan perlakuan terbaik untuk pembentukan embrio somatik fase globular dengan jumlah rata-rata sebanyak 271.

\section{UCAPAN TERIMA KASIH}

Ucapan terima kasih disampaikan kepada saudara Suwandi yang telah membantu penulis untuk mengolah data yang dibutuhkan dalam tulisan ini.

\section{DAFTAR PUSTAKA}

Ammirato, P.V. 1983. Embryogenesis. In Evans, D.A., W.R. Sharp, P.V. Ammirato dan Y. Yamada (eds.). Handbook of Plant Cell Culture (1). Techniques for Propagation and Breeding. McMillan. New York. P. $82-90$.
Dai, C.L., X. Tan, Y.G. Zhan, Y.Q. Zhang, S. Xiao, Y. Gao, D.W. Xu, T. Wang, X.C. Wang dan X.L. You. 2011. Rapid and repetitive plant regeneration of Aralia elata Seem. via somatic embryogenesis. Plant Cell Tissue and Organ Culture 104: $125-130$.

Capuana, M. dan P.C. Debergh. 1997. Improvement of the maturation and germination of horse chesnut somatic embryos. Plant Cell Tissue and Organ Culture 48: 23 - 29.

Concha, D.M, S. Mayes, G. Ribas, M.R. Davey. 2012. Somatic embryogenesis from zygotic embryos and shoot-tips of the Chilean tree Gomortega keule. Plant Cell Tissue and Organ Culture 109: 123 $-130$

Guevin, T.G. dan E.G. Kirby. 1997. Induction of embryogenesis in cultured mature zygotic embryos of Abies fraseri (Pursh) Poir. Plant Cell Tissue and Organ Culture 49: 219 - 222.

Gunasekara, D.S., E.S. Scott dan A.N. Rao. 1988. Suspension culture of the dipterocarp Shorea roxburghii G. Don. Somatic Cell Genetic of Woody Plant. p 137 - 141.

Indrianto, A. 2002. Kultur jaringan tumbuhan. Fak. Biologi UGM. Yogyakarta.134 hal.

Lee, K.S., J.C. Lee dan W.Y. Soh. 2002. High frequency plant regeneration from Aralia cordata somatic embryos. Plant Cell Tissue and Organ Culture 68: 241 -246 .

Leyser, O. dan S. Day. 2003. Mechanism in Plant Development. Blackwell Publ. 241 p.

Litz, R.E., R.C. Hendrix, P.A. Moon dan V.M. Chavez. 1998. Induction of embryogenic mango cultures as affected by genotype, explanting, 2,4-D and embryogenic nurse culture. Plant Cell Tissue and Organ Culture 53: 13 - 18.

Molina, D.M., M.E. Aponte, H. Cortina dan G. Moreno. 2002. The effect of genotype and explant age on somatic embryogenesis of Coffee. Plant Cell Tissue and Organ Culture 71: 117-125.

Nanda, R.M dan G.R. Rout. 2003. In vitro somatic embryogenesis and plant regeneration in Acacia arabica. Plant Cell Tissue and Organ Culture 73: 131 - 135.

Noerhadi, E. 1974. Kultur jaringan tumbuhan sebagai bahan penyelidikan dan potensinya dalam pembangunan Negara. 
Pidato pengukuhan guru besar tetap ITB. Penerbit ITB. Bandung.

Nugent, G, S.F. Chandler, P. Whitemean dan T.W. Stevenson. 2001. Somatic embryogenesis in Eucalyptus globules. Plant Cell Tissue and Organ Culture 67: $85-88$.

Ortiz, B.O.C., M.E.P. Reyes dan P.E.M. Balch. 2000. Somatic embryogenesis and plant regeneration in Acacia farnesiana and A. schaffneri. In vitro Cell Dev. Biol. Plant 36: $268-272$.

Rai, V.R dan J. McComb. 2002. Direct somatic embryogenesis from mature embryos of sandalwood. Plant Cell Tissue and Organ Culture 69: 65 - 70.

Rani, V. dan Raina, S.N. 2000. Genetic fidelity of organized meristems derived micropropagated plants: a critical reappraisal. In vitro Cell Dev Biol-Plant 36: $319-330$.

Rohani, E.R, I. Ismanizan, N.M. Noor. 2012. Somatic embryogenesis of mangosteen. Plant Cell Tissue and Organ Culture 110: $251-259$.

Rustam, D. dan H. Simatupang. 2005. Suatu kajian terhadap pelaksanaan pengawasan dan penegakan hukum disektor kehutanan. Surili 34 (1): 8g $8 \mathrm{i}$.

Sagare, AP, K.Suhasini dan KV. Krishnamurthy. 1993. Plant regeneration via somatic embryogenesis in chick pea (Cicer arietinum L). Plant Cell Reports 12 : $652-655$.

Sastrapradja, S.D. 2005. Pengelolaan sumber daya genetik tumbuhan hutan. Makalah dalam Seminar Nasional Peningkatan Produktivitas Hutan, Peran Konservasi Sumber daya genetik, Pemuliaan dan Silvikultur dalam mendukung Rehabilitasi Hutan, Yogyakarta. 26 - 27 Mei. 9 hal.

Shimizu, K., N. Nagaike, T. Yobuya dan T. Edachi. 1997. Plant regeneration from suspension culture of Iris gemanica. Plant Cell Tissue and Organ Culture 50 : $27-31$.

Singh, R.P., S.J. Murch dan P.K. Saxena. 1999. Role of nitrogen in morphogenesis in vitro. In Nitrogen nutrition in higher plants (eds.). Science Publ. Inc. USA. p. $205-223$.
Su, W.W., W.I. Hwang, S.Y. Kim dan Y. Sagawa. 1997. Induction of somatic embryogenesis in Azadirachta indica. Plant Cell Tissue and Organ Culture 50 : $91-95$.

Umboh, M.I.J., S.A. Yani dan D.J. Lawalata. 1992. Proceeding of Tsukuba Workshop. Tsukuba Science City. BIO-REFOR. p. 112

Veisseire, P., L. Linossier dan A. Coudret. 1994. Effect of absisic acid and cytokinins on the development of somatic embryos in Havea brasiliensis. Plant Cell Tissue and Organ Culture $39: 219$ - 223.

William, E.G dan G. Mahasweran. 1986. Somatic embryogenesis: factors influencing coordinated behavior as an embryogenic group. In Santos, MO, E. Romano, K.S.C. Yotoko, M.L.P.Tinoco, B.B.A. Dias dan F.J.L. Aragao: Characterisation of the cacao somatic embryogenesis receptorlike kinase (SERK) gene expressed during somatic embryogenesis. Plant Science 168: 723 - 729

Yang, L, Y. Li dan H. Shen. 2012. Somatic embryogenesis and plant regeneration from immature zygotic embryo cultures of mountain ash (Sorbus pohuashanensis). Plant Cell Tissue and Organ Culture 109 : 547 - 556.

Yelnititis, E. Sapulete dan T. Herawan. 2002. Embriogenesis somatik pada $S$. leprosula, S. selanica dan S. pinanga. Laporan Tahunan P3BPTH (tidak dipublikasikan).

Yelnititis. 2007. Induksi embrio somatik Shorea pinanga dengan 2,4-D dan NAA. Jurnal Penelitian Hutan Tanaman vol 4 supp. 1 : $235-243$.

Yelnititis. 2008. Regenerasi tanaman Shorea pinanga melalui embryogenesis somatic. Jurnal Penelitian Hutan Tanaman 5 (1) : $33-44$.

Yeung, E.C. 1995. Structural and developmental, patterns in somatic embryogenesis. In Thorpe, T.A (eds.). In vitro embryogenesis in plants. Kluwer Acad. Publ. Netherland p. $205-230$.

Yoeup, PK, D. Chakrabarty. 2003. Micropropagation of woody plants using bioreactor. In : Jain SM, K. Ishii (eds). Micropropagation of woody trees and fruits. Forestry Sciences 75 : $735-$ 755. 
Young, A,, C. Miller, GA. de Mayolo, JD. Swanson, S. Phisak, S. Maximova dan M. Guiltinan. 2003. Cacao Tissue Culture Protocol Book version 1.4. Pennstate Collage of Agriculture Sciences. USDA. Pennsylvania State University. Jan $27^{\text {th }}$. 
Jurnal Pemuliaan Tanaman Hutan

Vol 7 No. 2, September 2013, 73 - 84 